\title{
Transforming growth factor- $\beta$ as a differentiating factor for cultured smooth muscle cells
}

\author{
J.P. Gawaziuk, X. Ma, F. Sheikh, Z-Q. Cheng, P.A. Cattini and N.L. Stephens
}

ABSTRACT: The aim of the present study was to determine whether the development of supercontractile smooth muscle cells, contributing to the nonspecific hyperreactivity of airways in asthmatic patients, is due to transforming growth factor (TGF)- $\beta$.

In cultured smooth muscle cells starved by removal of $10 \%$ foetal bovine serum for 7 days, growth arrest was seen; $30 \%$ became elongated and demonstrated super contractility. Study of conditioned medium suggested that the differentiating factor was TGF- $\beta$. Sodium dodecyl sulphate-polyacrylamide gel electrophoresis (SDS-PAGE) was carried out on conditioned medium from the arrested cells. Two protein bands were identified as matrix metalloproteinase (MMP)-2 and TGF- $\beta 1$. To determine second messenger signalling by SMAD2, Western blotting and confocal microscopy were employed.

Conditioned medium from arrested cultures showed the presence of MMP-2 and TGF- $\beta 1$, as revealed by SDS-PAGE; 68- and 25-kDa bands were seen. Differentiation was confirmed by upregulation of marker proteins, smooth muscle type myosin heavy chain and myosin light chain kinase. Confirmation was obtained by downregulating these proteins with decorin treatment, which reduces the levels of active TGF- $\beta$ and an adenoviral dominant-negative vector coding for a mutated type II TGF- $\beta$-receptor. Activation of second messenger signalling was demonstrated immunocytochemically by the presence of phosphorylated SMAD2 and SMAD4.

Transforming growth factor- $\beta$ is likely to be the differentiating factor responsible for the development of these supercontractile smooth muscle cells. The development of such cells in vivo after cessation of an asthmatic attack could contribute to the nonspecific hyperreactivity of airways seen in patients.

KEYWORDS: Decorin, double mass spectrometry, matrix metalloproteinase-2, SMAD2, transforming growth factor- $\beta 1$, transforming growth factor- $\beta$-RII

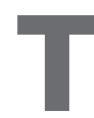
he most significant advance [1-5] in the pathogenesis of chronic asthma has been the recognition that it is a chronic inflammatory disease associated with hypertrophy and hyperplasia of airway smooth muscle cells (ASMC). As the ASMC changes, engendered by hyperplasia, are accompanied by modulation of the cell to a secretory phenotype with reduced contractility, it may seem that asthmatic airway narrowing is due more to geometric alterations than increased contractility. However, increased contractility may yet be an important factor.

\section{Arrested ASMC in culture}

Support for the view stated above has come from studies of cultured canine tracheal smooth muscle cells (TSMC). These cells are normally of synthetic type and feebly contractile. However, if replication under $10 \%$ foetal bovine serum (FBS) stimulus is arrested at $70 \%$ confluence by serum withdrawal, $30 \%$ of cells change their phenotype and became supercontractile [6]. They express mature smooth muscle type contractile and regulatory proteins and appear to be differentiating into mature cells.

\section{Transforming growth factor- $\beta 1$}

Evidence suggests a contribution of factors, such as transforming growth factor (TGF)- $\beta$, to the pathogenesis of asthma $[7,8]$. TGF- $\beta$ is secreted as a latent complex $[9,10]$. Several processes can activate TGF- $\beta$, allowing it to bind to its type II serine/threonine kinase receptor (T $\beta R)$ II [10]. Ligand binding to T $\beta$ RII causes phosphorylation of the intracellular domain of T $\beta R I$. In turn, T $\beta$ RI phosphorylates receptor-activated Smad2

\section{AFFILIATIONS}

Dept of Physiology, Faculty of Medicine, University of Manitoba, Winnipeg, MB, Canada.

CORRESPONDENCE

N.L. Stephens

Dept of Physiology

Faculty of Medicine

John Buhler Research Centre

Room 537

715 McDermot Avenue

Winnipeg

MB R3E 3P4

Canada

Fax: 12047893941

E-mail: nstephe@ms.umanitoba.ca

Received:

December 012005

Accepted after revision:

June 192007

SUPPORT STATEMENT

Funding support for the research

described in this paper was obtained from the Manitoba Institute of Child Health, Section of Biology of Breathing (Winnipeg, MB, Canada).

STATEMENT OF INTEREST Statements of interest for

N.L. Stephens and for the study itself can be found at www.erj.ersjournals. com/misc/statements.shtml

European Respiratory Journal Print ISSN 0903-1936 Online ISSN 1399-3003 
(R-Smad2), which forms a complex with common mediator Smad4 (co-Smad4); this dimer, either directly or indirectly, interacts with various target genes, after translocating from the cytoplasm to the nucleus.

\section{Decorin}

As receptor activation requires binding of active TGF- $\beta$, activation of latent TGF- $\beta$ is needed. This is brought about by activity of matrix metalloproteinase (MMP)-2 [11-13]. Decorin, another component of the extracellular matrix, binds only the activated and not the latent form of TGF- $\beta$ [4] and subsequently blocks TGF- $\beta$ function [14, 15], suggesting a regulatory role. Previous research has shown co-localisation of decorin and TGF- $\beta$ in human connective tissues $[9,16]$, which may thus serve as a reservoir for TGF- $\beta$.

ASMC release TGF- $\beta$, which may promote differentiation. Serum from conditioned medium of starved airway smooth muscle cells in culture has been reported to be associated with a new supercontractile phenotype [6]. It has been speculated that under these conditions, TGF- $\beta$ is released, which, in turn, induces differentiation by an autocrine effect.

\section{Over-expression of adenovirus-mediated dn-TGF- $\beta$-receptor type II}

T $\beta$ RII is required for TGF- $\beta$ signalling [17]. The latter acts by binding to T $\beta$ RII, which then activates T $\beta R I$ [18]. Use of a mutated T $\beta$ RII has been shown to block TGF- $\beta$ signalling [1925]. This block is affected by prevention of phosphorylation of downstream effectors, such as Smad proteins [21]. This technique has been reported to be effective in a variety of cell types [25, 26].

\section{Smad proteins}

In most mammalian systems, T $\beta R I$ phosphorylates Smad2 (RSmad2), which forms a complex with co-Smad4; this translocates to the cell nucleus with the aid of the cytoplasmic protein importin [23] and results in binding of the complex to the appropriate gene promoters. Although Smad complexes do bind to DNA, the low affinity of this reaction necessitates binding of additional factors for efficient transcription [21].

The results reported herein suggest a mechanism for differentiation of airway smooth muscle cells. The present authors show that serum starvation of cultured cells is accompanied by an increase in the expression of TGF- $\beta$ I and MMP-2. This is accompanied by switching of expression of proliferating smooth muscle cell type proteins (nonmuscle types of myosin heavy chain (MHC) and myosin light chain kinase (MLCK)) to those of differentiated cells (smooth muscle type (sm)MHC and kinase). These changes can be partially prevented with the use of decorin blocking antibodies and by transfection with adenovirus-dominant negative T $\beta$ RII constructs. While such differentiation has been reported in vascular [27] and other smooth muscle types, the current report is among the first for airway smooth muscle $[6,28]$, and the only one in which the role of TGF- $\beta$ has been studied as a differentiating factor. This process of differentiation could occur in any smooth muscle where inflammation and proliferation occur.

\section{MATERIALS AND METHODS}

\section{Cell culture}

Canine TSMC were isolated according MA et al. [6]. The procedures were those recommended by the Animal Ethics Committee of the present authors' institution (University of Manitoba, Winnipeg, MB, Canada). For each experiment, a seeding density of $5.0 \times 10^{4}$ cells $\cdot \mathrm{cm}^{-2}$ was used, plated onto $100-\mathrm{mm}$ diameter plastic culture dishes. At 70\% confluence, cultures were switched to serum-free medium (F12) containing selenium (1 nM), insulin (1 nM) and transferrin (65.8 nM; SIT), and maintained in this arrested state for as long as required. Five cell lines were used for each group of animals.

\section{Collection of conditioned medium}

After incubation of cells for the required period of time, conditioned medium was collected from cultures, placed in a sterile Eppendorf tube with $1 \mathrm{mg} \cdot \mathrm{mL}^{-1}$ each of leupeptin, aprotinin and pepstatin, and stored at $-80^{\circ} \mathrm{C}$.

\section{Measurement of single cell mechanics}

Arrested cells were obtained as described above. The methodology has been described in detail previously by MA et al. [6]. Individual cells could be separated from the bundles and used for studies of their mechanical properties. After an adequate number of bundles (20-30) were collected from culture dishes, they were used for studies of MHC and MLCK isoforms. Cell length was measured with an inverted microscope. Maximum shortening of cells was elicited by applying electrical pulse stimulation $(10 \mathrm{~Hz}, 40 \mathrm{~V}, 1 \mathrm{~ms}$ width). Images of the cells were recorded using a video camera mounted on the microscope. Cell shortening was then analysed for maximum shortening capacity $(\Delta L \max )$ and maximum velocity of shortening $\left(V_{\mathrm{o}}\right)$. The shortening measured was that under zero applied load. The increased $V_{\mathrm{o}}$ and $\Delta L$ max elicited by electrical field stimulation have operatively been termed as "supercontractility" [6].

\section{Western blotting, immune Western blotting and immune detection}

Cultured, confluent, canine TSMC (70\%) were lysed in $150 \mu \mathrm{L}$ modified RIPA lysis buffer ( $\mathrm{pH} 8.0 ; 40 \mathrm{mM}$ Tris ( $\mathrm{pH} 8.0$ ), $150 \mathrm{mM} \mathrm{NaCl}, 1 \%$ IGEPAL (NP-40), 1\% deoxycholic acid, $5 \mu \mathrm{g} \cdot \mathrm{mL}^{-1}$ each of leupeptin, pepstatin and aprotinin, $20 \mathrm{mM}$ $\mathrm{NaF}$ ). Protein content was measured using the bicinchoninic acid method. Protein extracts $(25 \mu \mathrm{g})$ and broad-range molecular weight markers were separated by $8-12 \%$ (weight/ volume $(\mathrm{w} / \mathrm{v})$ ) sodium dodecyl sulphate-polyacrylamide gel electrophoresis (SDS-PAGE) and then transferred to nitrocellulose membranes. After blocking, membranes were incubated overnight at $4^{\circ} \mathrm{C}$, in solution with a dilution of $1 \mu \mathrm{g} \cdot \mu \mathrm{L}^{-1}$ of monoclonal antimouse MLCK (Sigma clone K36; Sigma, St. Louis, MO, USA), anti- $\alpha$-smooth muscle actin (Sigma clone 1A4), anti-MHC (Sigma clone HSM-V), anti-rabbit T $\beta R I I$, antirabbit TGF- $\beta \mathrm{I}$ antibody or polyclonal anti-mouse MMP-2 antibodies in $0.01 \%$ TBS-T containing 5\% skimmed milk powder. Blots were washed and then incubated with streptavidin-horseradish peroxidase conjugate $(1: 4,000)$ diluted in TBS-T containing $1 \%$ skimmed milk powder for $1 \mathrm{~h}$ at room temperature. Blots were visualised with enhanced chemiluminescence, and subjected to densitometry. 


\section{Fluorescence immunocytochemistry}

Immunofluorescence analysis was performed as previously described [6]. Freshly isolated cells were plated in six-well dishes on acidified, alcohol-treated coverslips. At 70\% confluence, cells were arrested for 7 days, fixed in 1\% paraformaldehyde-PBS ( $\mathrm{pH} 7.6$ ), permeabilised with $0.1 \%$ Triton $\mathrm{X}-100$ and then blocked. Primary antibodies (diluted to 1:25) included rabbit anti-smooth muscle (sm)MLCK, mouse antismMHC, and anti-smooth muscle $\alpha$-actin ( $\alpha$-SMA). After treatment with secondary antibodies, coverslips were washed and nuclei were stained with Hoechst 33342 dye $\left(20 \mu \mathrm{g} \cdot \mathrm{mL}^{-1}\right.$; Molecular Probes, Eugene, OR, USA). Slides were photographed using a Nikon Diaphot microscope.

Translocation of Smad2 complex from cytoplasm to nucleus was detected by confocal microscopy employing phosphospecific Smad2 antibodies.

\section{TGF- $\beta$ ELISA}

The Duo-Set ${ }$ TGF- $\beta$ ELISA kit (R\&D Systems, Minneapolis, MN, USA) was used to determine TGF- $\beta$ content in neutral culture medium (representing active TGF- $\beta$ ) or culture medium that was acidified and subsequently neutralised (representing total TGF- $\beta$ ) according to the manufacturer's instructions. Mouse anti-TGF- $\beta$ capture antibody $(100 \mu \mathrm{L})$ were coated onto a 96-well microplate overnight at room temperature. After washing $(3 \times 200 \mu \mathrm{L})$ with wash buffer (0.05\% Tween-2 in PBS, pH 7.2-7.4), samples were blocked with $200 \mu \mathrm{L}$ blocking buffer (5\% Tween-20, 5\% sucrose in PBS with $0.05 \% \mathrm{NaN}_{3}$ ) for a minimum of $1 \mathrm{~h}$ at room temperature. The plate was washed $(3 \times 200 \mu \mathrm{L})$ with wash buffer, and then incubated with $100 \mu \mathrm{L}$ biotinylated chicken anti-human TGF- $\beta$ detection antibody (diluted to $300 \mathrm{ng} \cdot \mathrm{mL}^{-1}$ in reagent diluent) for $24 \mathrm{~h}$ at room temperature. The plate was then washed $(3 \times 200 \mu \mathrm{L})$ with wash buffer and then incubated with $100 \mu \mathrm{L}$ streptavidin-horseradish peroxidase (diluted 1:2,000) in each well for $20 \mathrm{~min}$ at room temperature and shielded from direct light. The substrate solution consisted of a 1:1 mixture of Colour Reagent A $\left(\mathrm{H}_{2} \mathrm{O}_{2}\right)$ and Colour Reagent B (tetramethylbenzidine). Fifty microlitres of $1 \mathrm{M} \mathrm{H}_{2} \mathrm{SO}_{4}$ were used to halt the colourimetric reaction. The optical density of the coloured complex was read using a Power Wave microplate reader employing KC4 software on a Windows-Based PC set at $562 \mathrm{~nm}$, from which the concomitantly measured value of density read at $450 \mathrm{~nm}$ was subtracted to yield a corrected optical density. TGF- $\beta$ concentrations in the samples were calculated by a four-parameter/coefficient logistic regression equation with the KC4 program.

\section{Double mass spectrometric analysis of phosphopeptides}

To examine differential expression of proteins, $1 \mathrm{~mL}$ conditioned media was collected from serum-starved, arrested TSMC. The medium was dialysed in PBS for $24 \mathrm{~h}$ at $4^{\circ} \mathrm{C}$ and proteins were separated using $10 \%(\mathrm{w} / \mathrm{v})$ SDS-PAGE, and stained with the Silver Staining Kit (Protein; Amersham, Piscataway, NJ, USA) according to manufacturer's instructions. An $\sim 68 \mathrm{kDa}$ band was seen, excised and subjected to reduction, carboxyamidomethylation and digestion with trypsin. Tryptic peptides were analysed by microcapillary, reverse-phase, highperformance liquid chromatography and nano-electrospray tandem mass spectrometry at Harvard Microchemistry and
Proteomics Analysis Facility (Cambridge, MA, USA). Peptide sequencing was also carried out. To identify potential matches with the present sequencing results, homology searches were conducted with the aid of the Basic Local Alignment Search Tool (BLAST) algorithm [29].

\section{Decorin pre-treatment}

Decorin pre-treatment can be used to partially block increased TGF- $\beta$ I protein accumulation in conditioned medium from serum-deprived cell cultures. Decorin regulates matrix assembly by binding to collagen $[9,16]$. It also binds several other proteins, important among which is TGF- $\beta$ [16]. Co-localisation of decorin and TGF- $\beta$ has been reported in bronchial biopsies [30]. The complex of the two may serve as a reservoir for TGF- $\beta$ from where it can be liberated by appropriate stimuli. Recombinant human decorin was purchased from a commercial source in $100 \mu \mathrm{g}$ lots and was diluted in $1 \mathrm{~mL}$ of $10 \mathrm{nM}$ PBS free of $\mathrm{Ca}^{2+}$ and $\mathrm{Mg}^{2+}$. In experiments that required decorin, the $100 \mathrm{~nm}$ dismeter culture dish that contained canine airway myocytes was rinsed with $100 \mathrm{nM}$ PBS free of $\mathrm{Ca}^{2+}$ and $\mathrm{Mg}^{2+}$ $(2 \times 3 \mathrm{ml})$ and samples were treated with $5 \mu \mathrm{g} \cdot \mathrm{mL}^{-1}$ in $3 \mathrm{~mL}$ of F-12 medium containing 1\% insulin-transferrin-selenium supplements (ITS; Gibco/BRL, Burlington, ON, USA) for $24 \mathrm{~h}$. At the completion of the treatment, the culture dish was rinsed with $10 \mathrm{nM}$ PBS free of $\mathrm{Ca}^{2+}$ and $\mathrm{Mg}^{2+}(2 \times 3 \mathrm{~mL})$ and $10 \mathrm{~mL}$ of F-12 medium containing 1\% ITS was added and cells were further serum-deprived for the required duration of time.

\section{Transfection with adenovirus vector containing mutated T $\beta R \boldsymbol{I I}$}

Canine TSMC were transfected with an adenoviral vector expressing a mutated human type T $\beta$ RII that was truncated of its kinase domain (Adv-dn T $\beta R I I)$; it was made by the present authors (F. Sheikh and P.A. Cattini). This construct abrogates TGF- $\beta$ ligand-mediated signalling because deletion of the cytoplasmic serine/threonine domain prevents signal propagation by intracellular mediators [19]. Seventy percent confluent cultures were transfected with Adv-dn T $\beta R I I$ (multiplicity of infection (MOI) 10) or control adenovirus (Adv-TrLacZ, which expressed bacterial galactosidase), in serum-free medium for $24 \mathrm{~h}$ while being incubated at $37^{\circ} \mathrm{C}$ in $5 \% \mathrm{CO}_{2}$, and then were serum-starved for a further 6 days.

\section{X-gal staining of fixed cells}

Canine TSMC were transfected with Adv-TRLacZ in serumfree medium for $24 \mathrm{~h}$ while being incubated at $37^{\circ} \mathrm{C}$ in $5 \% \mathrm{CO}_{2}$ and then serum-starved for a further 6 days. Cells were fixed with PBS containing $1.25 \%$ glutaraldehyde for $5 \mathrm{~min}$ at room temperature. Solution A ( $5 \mathrm{mM}$ potassium ferricyanide, $5 \mathrm{mM}$ potassium ferricyanide, $2 \mathrm{mM}$ magnesium chloride in PBS) was added in 1:40 dilution to X-gal (5-bromo-4-chloro-3indolyl- $\beta$-D-galactoside) to yield "final X-gal solution". Following two washes with $\mathrm{Ca}^{2+}$-free PBS, final X-gal solution was added and cells were incubated at $37^{\circ} \mathrm{C}$ in $5 \% \mathrm{CO}_{2}$ until a blue colour developed within 4-6 h. This staining was stopped when cells were rinsed with PBS containing $\mathrm{Ca}^{2+} / \mathrm{Mg}^{2+}$ and images were captured using a charge-coupled device camera.

\section{Gelatine substrate zymography}

To evaluate the effect of serum deprivation on expression and activity of MMP-2, conditioned medium was analysed by 
in-gelatine zymography. Briefly, samples $(50 \mu \mathrm{L})$ were run on an $8 \%(\mathrm{w} / \mathrm{v})$ SDS polyacrylamide gel containing $1 \mathrm{mg} \cdot \mathrm{mL}^{-1}$ porcine gelatine and washed three times to remove SDS and to allow enzyme renaturation. Gels were incubated overnight in MMP activation buffer $(10 \mathrm{mM}$ Tris $\mathrm{HCl}, \mathrm{pH} 7.5$, containing $1.25 \%$ Triton $\mathrm{X}-100,5 \mathrm{mM} \mathrm{CaCl} 2,1 \mu \mathrm{M} \mathrm{ZnCl}_{2}$ ) prior to staining with $0.25 \%(\mathrm{w} / \mathrm{v})$ Coomassie blue in the fixing solution. Cleared zones of gelatinolytic activity were observed upon destaining.

\section{Data analysis}

Data were expressed as mean \pm SE. A fixed-constants, one-way ANOVA was used to analyse the differences among mean values at different time-points. Duncan's new multiple-range test was used to determine which mean values were responsible for the differences indicated. To compare differences in protein expression, statistical significance was determined by unpaired t-test, with $\mathrm{p}<0.05$ considered significant.

\section{RESULTS}

\section{Morphology of the supercontractile phenotype of starved canine TSMC in culture}

Morphologically, two distinct groups of cells were seen on immunocytology of cultured, 15-day-arrested TSMC, as previously reported [6]. Figure 1 shows that one group appeared as small, flat, bright cells (short cells); numerically, these comprised $\sim 70 \%$ of the cells in culture and the second group (long cells) showed an elongated, spindle shape that was aligned in parallel bundles. HALAYKO et al. [31] have reported the presence of muscarinic M3 receptors on the sarcolemma of the arrested cells; gap junctions were also seen between the latter types of cells. They were found to possess a shining sarcolemma and were (mean \pm SE) $190 \pm 25.5 \mu \mathrm{m}$ in mean length on the seventh day of serum deprivation. Numerically, they comprised $28.5 \pm 4.6 \%$ of all cells, but by virtue of their cytoplasmic volume occupied almost $40 \%$ of the total area of the dish. Due to their super-contractility, an attempt was made to determine whether these cells were transforming into skeletal muscle cells. However, in five experiments, no expression of sarcomeric $\mathrm{MHC}$, troponin $\mathrm{C}$ or $\mathrm{T}$, or $\mathrm{MyoD}$ was observed.

\section{Mechanics of the supercontractile phenotype of canine TSMC in culture: marker proteins}

The shortening capacity (percentage of cell optimal length or Lo) versus time showed that the arrested cell shortened almost twice as much as the freshly isolated control cell (control). The $V_{\mathrm{o}}$ for the arrested cell was double that of the control.

Western blot analysis using specific antibodies showed that the long cells contained the smMHC, smMLCK and $\alpha$-SMA. Nonmuscle cell types of the same proteins were considerably downregulated. Proliferating small cells showed predominantly a mitotic pattern of protein expression, i.e. nonmuscle types of MHC and MLCK.

\section{Identification of an $\sim 68-k D a$ protein band present exclusively in serum-deprived conditioned media}

Tryptic peptides were analysed by microcapillary, reversephase, high-performance liquid chromatography-nano-electrospray tandem mass spectroscopy at Harvard Microchemistry and Proteomics Analysis Facility (Cambridge, MA, USA). To identify potential matches with the isolated protein, sequencing was carried out and yielded the following unique sequence: WYDVLR. To investigate whether serum starvation differentially expressed any proteins, conditioned medium from proliferating and 7-day serum-deprived canine TSMC was examined. An $\sim 68 \mathrm{kDa}$ protein band was seen (fig. 2), excised and subjected to reduction, carboxyamidomethylation and digestion with trypsin. Subsequent Western blot analysis with specific antibody confirmed this.

Figure 3a shows Western blots of MMP-2 of conditioned media obtained on days 3, 6 and 9 of serum starvation. Figure $3 b$ is a zymogram showing proteolytic activity of MMP-2 as a function of time.

\section{Increased duration of serum starvation}

Increased TGF- $\beta$ protein in conditioned medium obtained from cell cultures was subjected to an increased duration of serum starvation. The conditioned medium from canine TSMC was analysed for content of TGF- $\beta$ I protein. The medium was dialysed, proteins were separated using $8 \%(\mathrm{w} / \mathrm{v})$ SDS-PAGE, transferred to nitrocellulose and subjected to autoradiography. Immunoblotting of conditioned medium showed the TGF- $\beta$ protein content was high when the cell was proliferating (day 0 ), became absent at day 3 of starvation and then reappeared in increasing concentrations on days 6, 9 and 12. This indicates that the time course of TGF- $\beta$ protein expression in serumstarved cells mimicked that of MMP-2. It is noteworthy that, although the protein content had increased by day 9 , it was considerably less than that at day 0 . A similar increase in TGF- $\beta$ was demonstrated on day 6 using a Duoset ELISA kit (R\&D Systems, Minneapolis, MN, USA). Decorin pre-treatment attenuated the serum deprivation-induced increase in total and active TGF- $\beta$.

\section{Effect of decorin on TGF- $\beta 1$ protein expression}

An ELISA detected a significant increase in both active and total TGF- $\beta 1$ protein in conditioned medium that peaked at day 6 of serum starvation of the cultured cells.

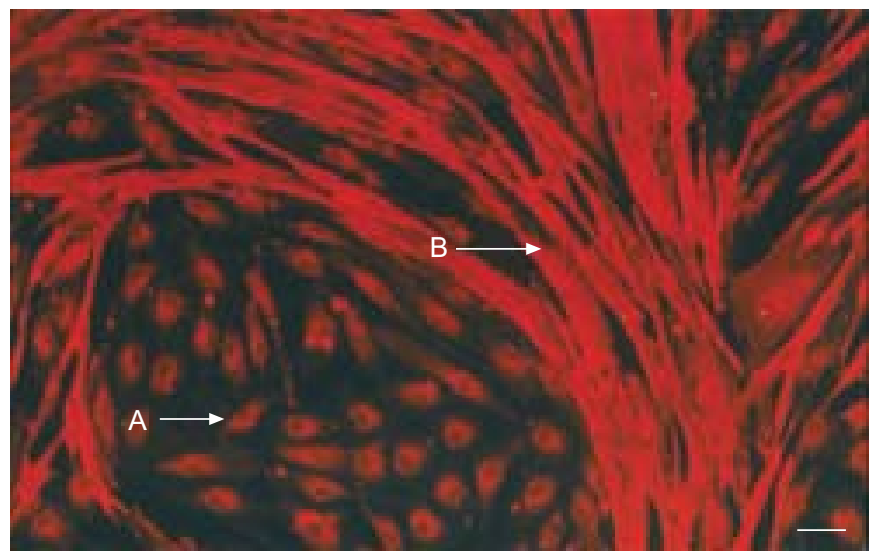

FIGURE 1. Indirect immunofluorescent staining, using a Cy3-conjugated secondary antibody, of smooth muscle myosin heavy chain (1:100) in canine airway myocytes that were serum starved for 15 days (magnification $\times 200$ ). A: short cells; B: long cells. Scale bar $=5 \mu \mathrm{m}$ 


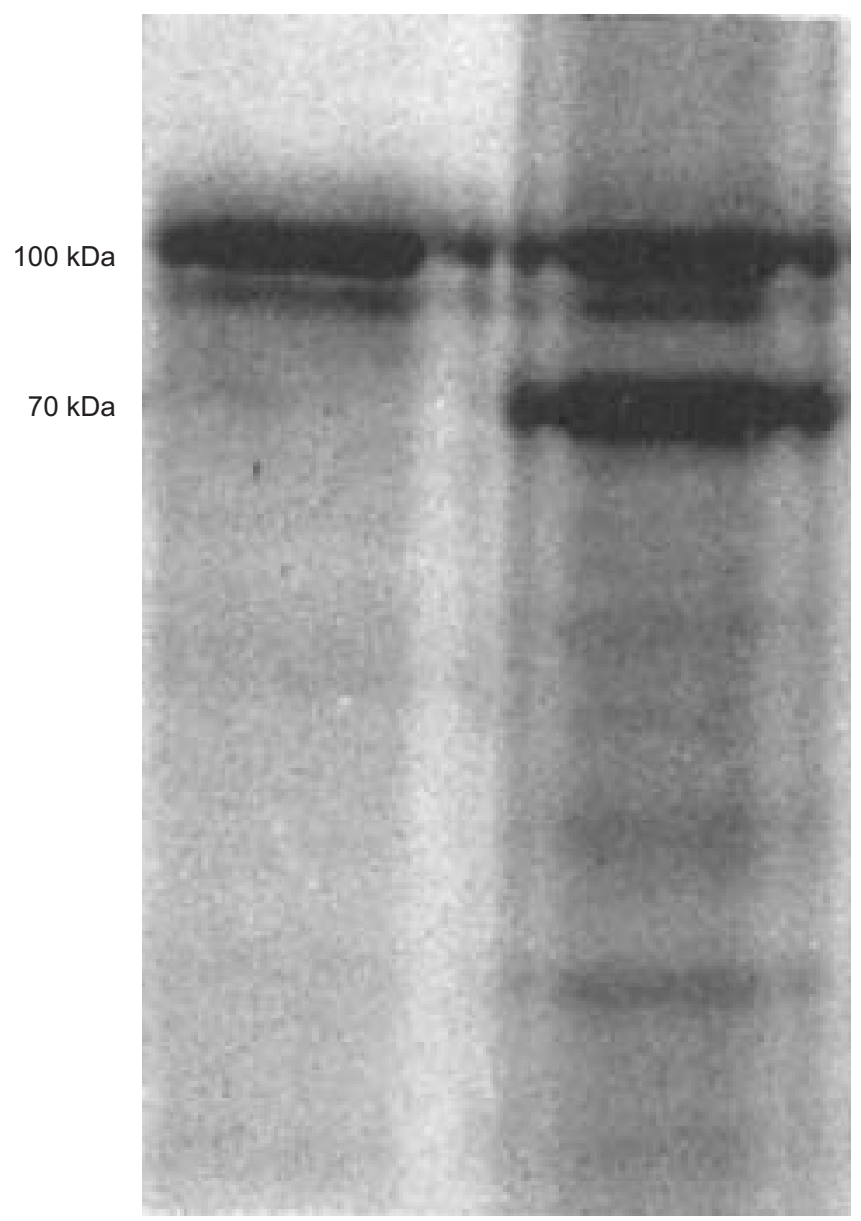

FIGURE 2. Conditioned medium from confluent, serum-fed cell cultures $48 \mathrm{~h}$ after their last feed (lane 1), and cells deprived of serum for 7 days (lane 2) were dialysed; proteins $\left(25 \mu \mathrm{g} \cdot \mathrm{lane}^{-1}\right)$ were fractionated via sodium dodecyl sulphatepolyarylamide gel electrophoresis, and silver-stained. A more intense $\sim 70 \mathrm{kDa}$ band in conditioned medium was obtained from cells deprived of serum for 7 days, than conditioned medium from proliferating canine airway myocytes. The figure is typical of those obtained from two samples that are representative of cell lines.

Decorin pre-treatment $\left(5 \mu \mathrm{g} \cdot \mathrm{mL}^{-1}\right)$ for $24 \mathrm{~h}$ prevented the serum deprivation-induced increase on day 6. A two-way ANOVA combined with Duncan's new multiple range tests was carried out to arrive at the above conclusions $(p<0.05)$.

\section{Effect of addition of exogenous TGF- $\beta$ on cell length}

TFG- $\beta$ was added to cultures of proliferating and arrested cells in concentrations of $1,2,10$ and $20 \mathrm{ng} \cdot \mathrm{mL}^{-1}$. These were added to separate cultures on days $1,3,4,7,10,11$ and 14 . Cell lengths were measured using an objective lens graticule. A threedimensional plot of the data is seen in figure 4 . The mean cell lengths for the serum-fed cells at day 6 , when the proliferation culture is $70 \%$ confluent, is $85.4 \pm 1.9 \mu \mathrm{m}(n=60)$. It is at this time that serum starvation is commenced for prospective "arrested" cells, which are termed day 0 cells. Their mean lengths were $81.3 \pm 1.8 \mu \mathrm{m}(\mathrm{n}=60)$. While peak length for proliferating cells was $106 \pm 2.0 \mu \mathrm{m}$ achieved on day 7 that for serum-starved, arrested cells was $155.7 \pm 4.2 \mu \mathrm{m}$. Thereafter, the arrested cells become smaller in length.

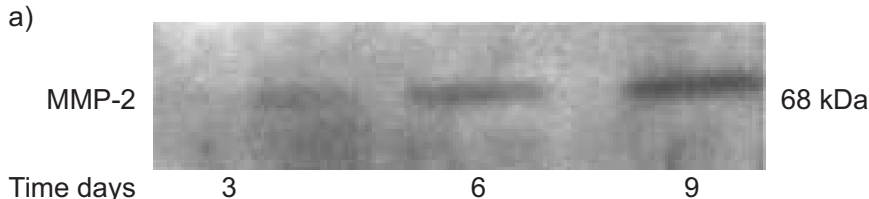

b)

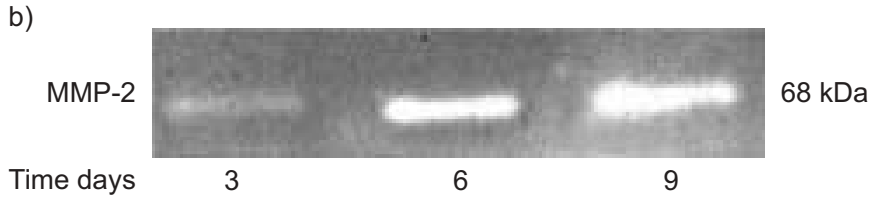

FIGURE 3. a) Conditioned medium from airway myocytes serum-deprived for 3,6 and 9 days. Proteins were separated by sodium dodecyl sulphatepolyacrylamide gel electrophoresis, transferred onto nitrocellulose, probed with anti-matrix-metalloproteinase (MMP)-2 antibody (1:1000) via Western blot. This representative blot shows that accumulation of MMP-2 began at day 3 of serumdeprivation, and increased with duration of serum-deprivation. b) A similar sample to that shown in (a), subjected to gelatine substrate zymography (performed in triplicate). This representative zymogram shows an $\sim 70 \mathrm{kDa}$ band of metalloenzyme proteolytic activity, corresponding to MMP-2 that showed increased activity beginning at day 3 of serum-deprivation, and increased with duration of serumdeprivation.

\section{$T \beta R I$ and $T \beta R I I$ cross-linking of decorin pre-treated serum- deprived cells}

Canine TSMC, serum-deprived for 7 days showed bands corresponding to proteins of appropriate molecular weights for T $\beta R I$ ( $53 \mathrm{kDa})$ and both the minor $(75 \mathrm{kDa})$ and the major $(110 \mathrm{kDa}$ ) isoforms of T $\beta$ RII (fig. 5). In canine TSMC, this confirms the presence of receptors which provide the proteins for TGF- $\beta$ signalling. Figure 5, lane 2 shows that decorin $\left(5 \mu \mathrm{g} \cdot \mathrm{mL}^{-1}\right.$ pre-treatment for $24 \mathrm{~h}$ followed by an additional 6 days of serum deprivation) partially blocked the appearance of T $\beta R I$ and T $\beta R I I$ bands. Competition studies (fig. 5) show that two-fold excess of TGF- $\beta\left(10 \mathrm{ng} \cdot \mathrm{mL}^{-1}\right)$ was able to block binding of ${ }^{125}$ I-TGF- $\beta$; this demonstrated binding specificity.

\section{TRRII protein accumulation in serum-deprived canine TSMC pre-treated with decorin}

No significant effect $(\mathrm{p}>0.05)$ of serum-deprivation or decorin pre-treatment on T $\beta R I I$ protein expression was seen. Combined with the cross-linking experiment data, these data suggest that TGF- $\beta$ blockade by decorin is likely to occur by disrupting the TGF- $\beta$ and T $\beta$ RII and T $\beta$ RI association, and that the effect is not compounded by altered levels of T $\beta R I I$.

\section{smMHC and smMLCK protein accumulation in canine TSMC pre-treated with decorin}

Western blots of experiments demonstrate that decorin significantly reduced smMLCK content (fig. 6a), while this is histographically confirmed in fig. 6b. The results of statistical analysis of data from six experiments are shown (fig. 6b). With respect to smMLCK, significant differences are seen on day 7 , while, with respect to smMHC (figs $6 c$ and d), significant differences are evident on days 3 and 7 . The disparity of timing in the onset of decorin's effect could be explained by the fact that smMHC and smMLCK are regulated by different mechanisms. 


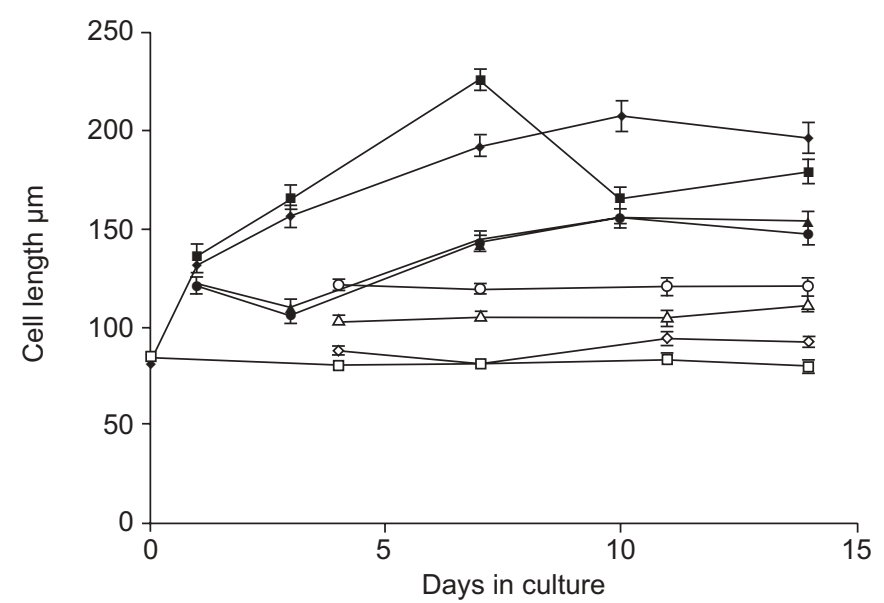

FIGURE 4. Cell length as a function of days in culture for each concentration of transforming growth factor (TGF)- $\beta$. The solid data points show values for the arrested (serum-starved) cells and the open data points represent values obtained from proliferating cells. The concentrations of TGF- $\beta$ are as follows: $\downarrow$ and $\diamond: 0 \mathrm{ng}$; - and $\square: 1 \mathrm{ng} ; \boldsymbol{\Delta}$ and $\triangle: 10 \mathrm{ng} ; \bullet$ and $O: 20 \mathrm{ng}$. It is noteworthy that cell length at day 0 with no TGF- $\beta$ added (control) is the same in the arrested and proliferating cells: $81.29167 \pm 10.68116$ versus $86.375 \pm 14.43003$ (mean \pm SD).

\section{Adv-dn T $\beta R$ II blocks accumulation of markers of TSMC phenotype}

To further substantiate the hypothesis that TGF- $\beta$ is a differentiating factor for TSMC in culture, its downregulation was expected to be associated with a change of phenotype from differentiated to synthetic, with a corresponding change in marker proteins. Canine TSMC were therefore transfected with an adenoviral vector expressing a mutated human type II TGF- $\beta$ receptor (Adv-decorin (dn)-TGF- $\beta$ RII). Previous research [32] indicated that this construct, whose serine/ threonine catalytic domain is truncated, would interfere with intracellular TGF- $\beta$ I- $\beta$ RII- $\beta$ RI signalling.

ASMC were cultured with 10\% FBS and then serum-starved for $24 \mathrm{~h}$. Careful analysis showed that the cells were morphologically homogeneous. The field shown was selected from four randomly chosen ones, taken from each of four different dishes of cells. These data indicate that the long, supercontractile phenotype of cell is initially not present in any appreciable number $(<5 \%)$, and develops later. A time-course study is needed to determine when the changes start. A culture of proliferating of myocytes was infected with Adv-T $\beta I I-\beta G a l$ $(\mathrm{MOI}=10)$. After $24 \mathrm{~h}$, serum-fed medium was replaced and cells were further serum deprived for an additional 6 days. The cells were then incubated with X-gal $\left(1 \mathrm{mg} \cdot \mathrm{mL}^{-1}\right)$ for $4 \mathrm{~h}$ at $37^{\circ} \mathrm{C}$ until the blue colour indicative of successful gene transfer of $\beta$-galactosidase was seen. The numbers of cells stained blue in which a nucleus could also be seen averaged $90 \%$, indicating efficient adenovirus infection.

Cultures at 70\% confluency were then transfected with Advdn-TGF-BRII (MOI 10) or control adenovirus (Adv-TGF- $\beta$ RLacZ, which expressed bacterial galactosidase) in serum-free medium for $24 \mathrm{~h}$, while incubated at $37^{\circ} \mathrm{C}$ in $5 \% \mathrm{CO}_{2}$ and then serum-starved for a further 6 days (fig. 6).

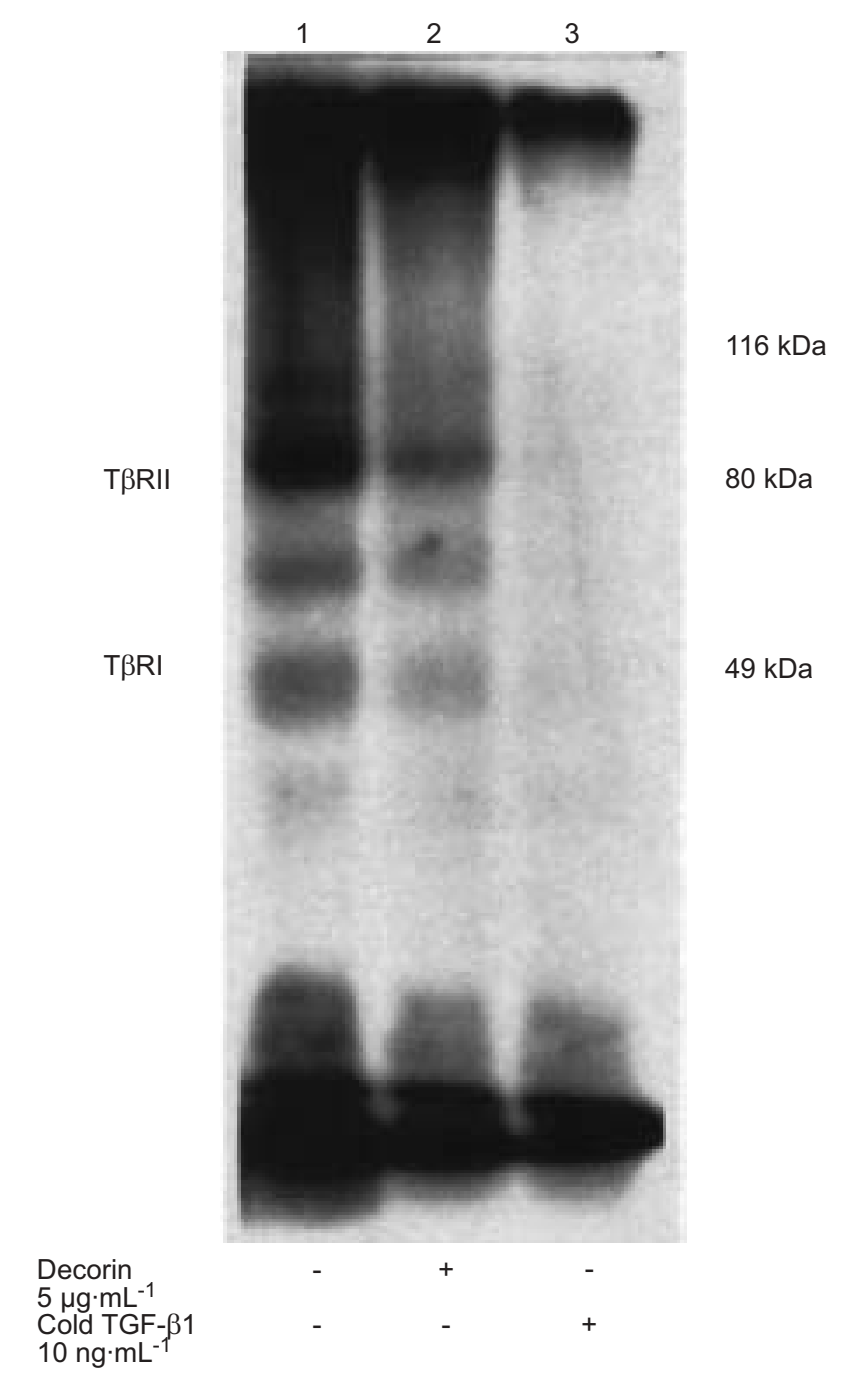

FIGURE 5. Canine airway myocytes, serum-deprived were cross-linked with $0.27 \mathrm{mM}$ disuccinimidyl suberate, and then incubated with ${ }^{125}$ I-transforming growth factor (TGF)- $\beta 1\left(5 \mathrm{ng} \cdot \mathrm{mL}^{-1}\right)$. Cell lysates $\left(25 \mu \mathrm{g} \cdot\right.$ lane $\left.^{-1}\right)$ were fractioned by $10 \%$ (weight/volume) sodium dodecyl sulphate-polyacrylamide gel electrophoresis followed by autoradiography. Cells that were serum-deprived for 7 days (lane 1) show bands of appropriate sizes, confirming the presence of transforming growth

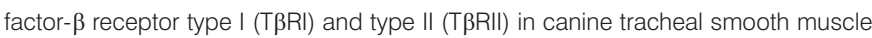
cell. Lane 2 shows cells pre-treated for $24 \mathrm{~h}$ with decorin $\left(5 \mu \mathrm{g} \cdot \mathrm{mL}^{-1}\right)$ and serumstarved for an additional 6 days before cross-linking. Lane 3 shows that two-fold excess cold TGF- $\beta 1$ (10 ng. $\left.\mathrm{mL}^{-1}\right)$ was able to block binding of ${ }^{125}$-TGF- $\beta 1$ to T $\beta R$ I and $T \beta R \|$, indicative of binding specificity.

Transfection with Adv-dn-TGF- $\beta$ RII was able to downregulate the serum starvation-induced accumulation of smMLCK and smMHC compared with the control vector (fig. 7). In addition, neither construct caused changes in expression of $\alpha$-SMA.

\section{Smad proteins}

By using antibodies against Smad2 proteins, a phosphospecific Smad2 protein was identified by Western blot. Using the same antibodies, immunocytochemistry of 7-day, serum-starved canine TSMC was carried out by confocal microscopy. Figure 8a shows Smad2 immunoreactive protein in the cytoplasm and nucleus of an arrested cell. The presence of a 
a)
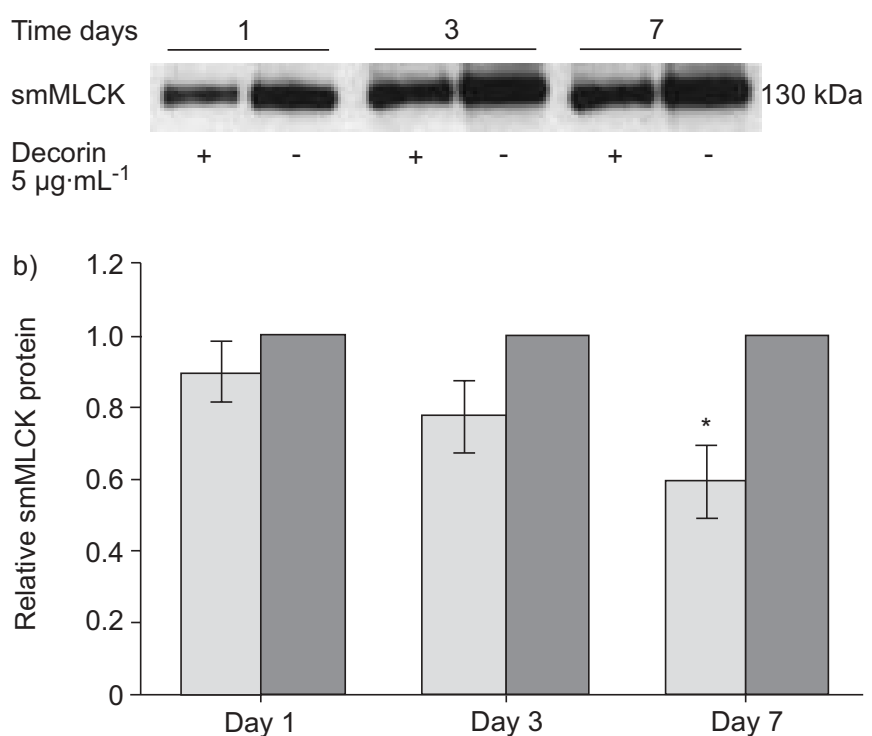

c)
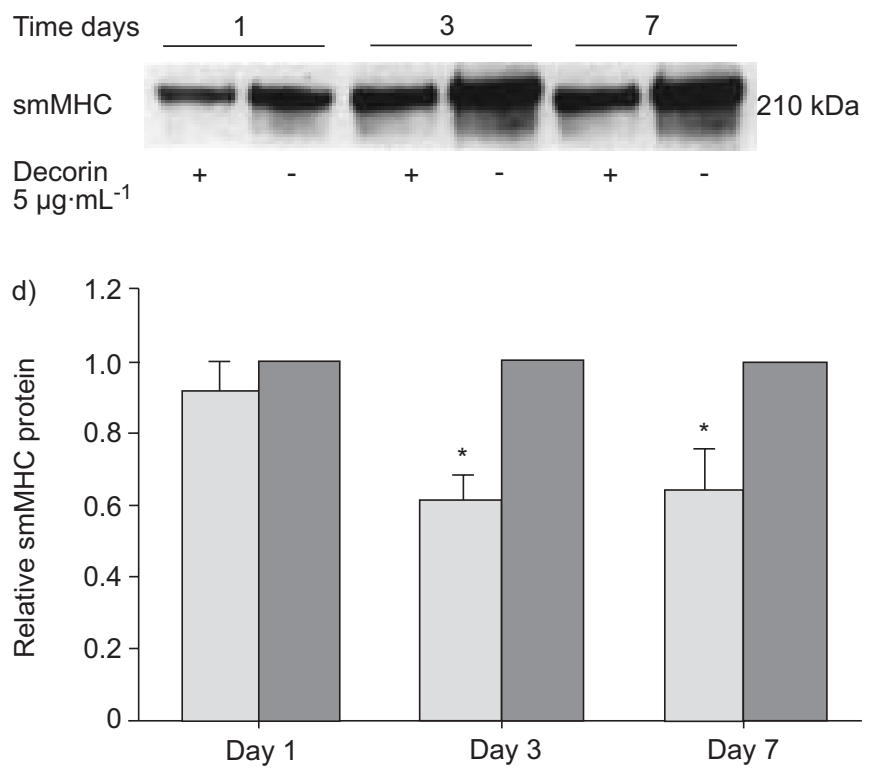

FIGURE 6. Canine airway myocytes were serum-deprived for 1,3 or 7 days and/or treated with decorin $\left(5 \mu \mathrm{g} \cdot \mathrm{mL}^{-1}\right)$ for the first $24 \mathrm{~h}$; serum-free medium was then replaced and cells were serum-deprived for the same total time as the first group. Proteins $\left(25 \mu \mathrm{g} \cdot\right.$ lane $\left.^{-1}\right)$ were fractionated by sodium dodecyl sulphatepolyacrylamide gel electrophoresis and probed with anti-smooth muscle myosin light chain kinase (smMLCK) or anti-smooth muscle myosin heavy chain (smMHC) antibodies (both at 1:1000) via Western blot. Experiments used two cell lines with three replications each and gels were performed in triplicate. Representative blots of a) smMLCK and c) smMHC are shown. These were quantified relatively by the ratio of protein obtained from serum-deprived cells divided by the amount of protein obtained from cells treated with decorin $\left(5 \mu \mathrm{g} \cdot \mathrm{mL}^{-1}\right)$ during the first $24 \mathrm{~h}$ of serum deprivation. b, d) Densitometry results are expressed as a mean \pm SE from three independent experiments. ${ }^{*}: p<0.05$ for the quantity of protein from airway myocytes that were serum deprived for 7 days (smMLCK) and for 3 or 7 days (smMHC) versus airway myocytes that were serum deprived for 1 day, respectively (paired t-test).

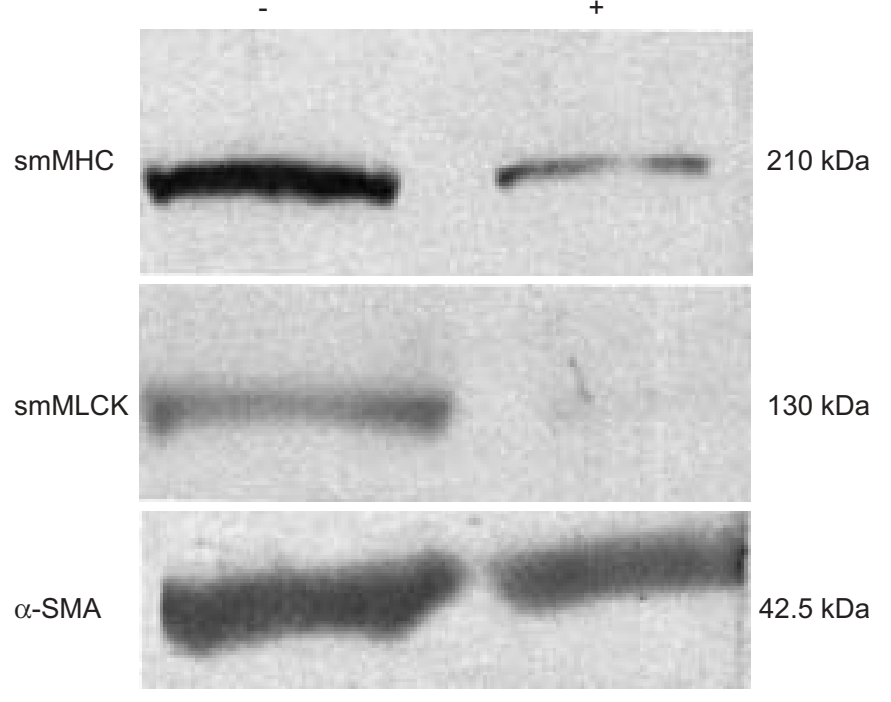

FIGURE 7. Western blots (using antibodies against smooth muscle myosin heavy chain (smMHC), smooth muscle myosin light chain kinase (smMLCK) and smooth muscle actin $(\alpha-S M A)$ ) of cell lysates of canine airway myocytes infected

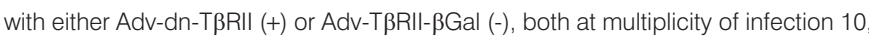
for $24 \mathrm{~h}$. Culture medium was then replaced and cells were serum deprived for an additional 6 days. Proteins $\left(25 \mu \mathrm{g} \cdot \mathrm{lane}^{-1}\right)$ were fractionated by sodium dodecyl sulphate-polyacrylamide gel electrophoresis, transferred on to nitrocellulose and were probed with antibodies against SMMHC, smMLCK and $\alpha$-SMA (all 1:1000) via Western blot. Experiments used two cell lines with three replications each and gels were performed in triplicate. Smooth muscle cells (SMC) infected with Adv-dn-TRRI decreased the accumulation of SMMHC and smMLCK versus SMC infected with

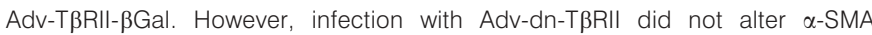

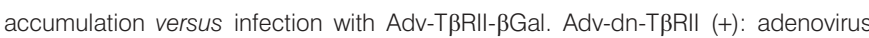
mediated dominant negative tumour necrosis factor (TGF)- $\beta$ type II receptor; AdvT $\beta$ RII- $\beta$ Gal (-): adenovirus-mediated TGF- $\beta$ type II receptor expressing bacterial $\beta$ galactosidase substituted for the kinase domain.

signal in the nucleus indicates translocation of Smad2 into the nucleus. Since Smad2 can only enter the nucleus when in a complexed form, the intranuclear location of Smad2 suggests that Smad4 is also present. Arrested cells treated with decorin indicate the accumulation of smaller amounts of Smad2 in the nucleus (fig. 8b).

\section{DISCUSSION}

The present study determined whether TGF- $\beta$, expressed in greater abundance in the conditioned medium of cultured cells subjected to serum starvation, could be a differentiation factor for the supercontractile, differentiated cells that develop under these conditions. To achieve this, marker proteins were identified for these cells. smMHC and MLCK proved to be effective as markers of the differentiated state. Proliferating cells show very low levels of these markers and instead upregulate levels of nonmuscle type MHC and nonmuscle type MLCK. The expression of these marker proteins should thus help identify the phenotype of the various cells.

The highest concentration of TGF- $\beta$ was found in medium from proliferating cells. On initiating serum starvation, levels dropped precipitously by day 3 and proliferation rate became considerably reduced. By days 6 and 9, the levels became increased, although never to the same levels as on day 0 . It is 

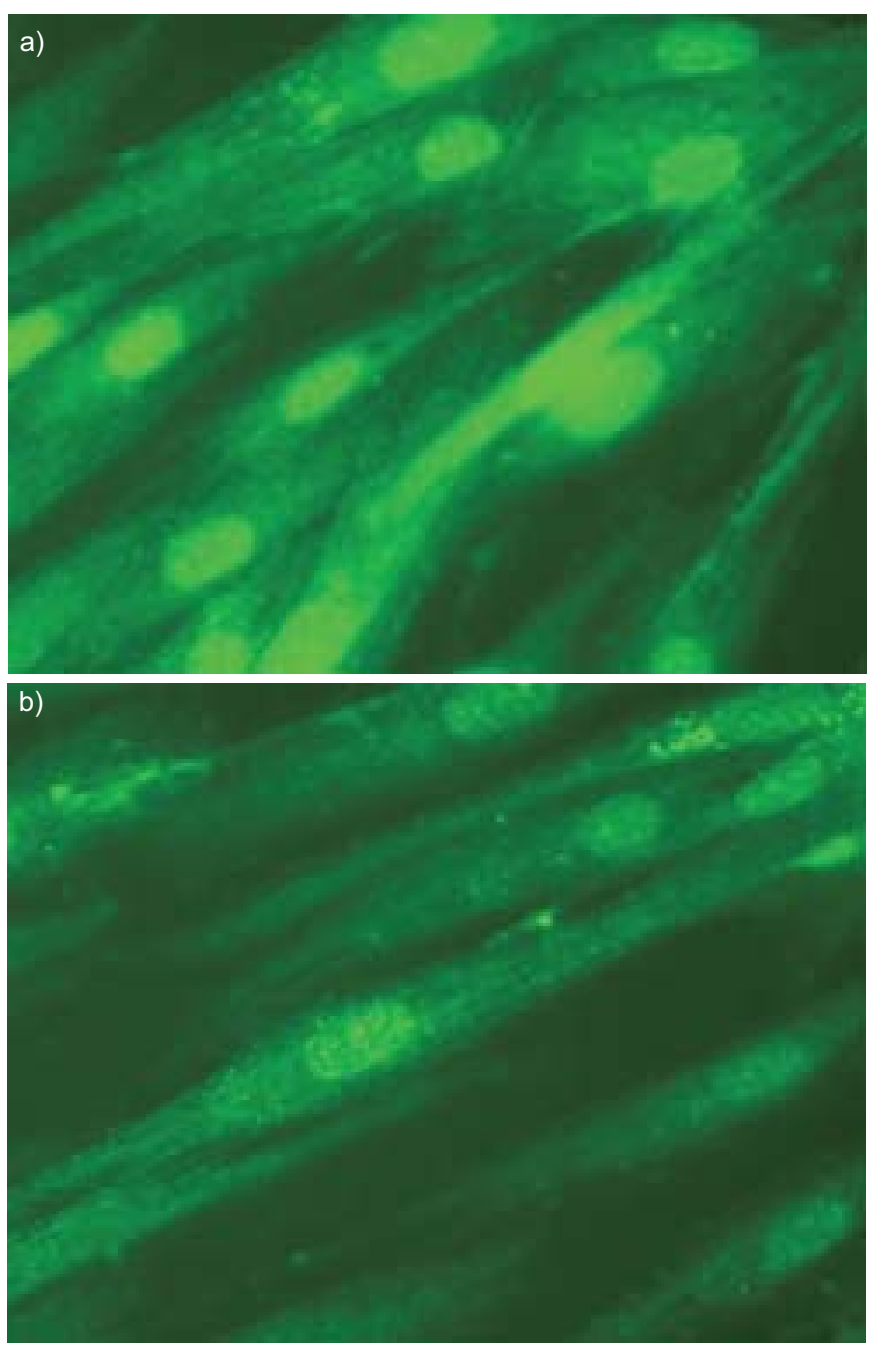

FIGURE 8. Immunocytochemistry of 7-day, serum-deprived airway smooth muscle cells. Phosphospecific Smad2 antibodies were used. a) Phosphospecific Smad2 signal in the cytoplasm and the nucleus. b) Similar immunocytochemical analysis, except cells were pre-treated with decorin, which bound transforming growth factor- $\beta 1$ in the extracellular matrix. A reduced intensity of green fluorescence is evident both in the cytoplasm and the nucleus, indicating reduced amounts of Smad proteins in these locations.

known that while high levels of TGF- $\beta$ favour proliferation, lower levels favour either apoptosis or differentiation. To test the hypothesis that TGF- $\beta$ in the levels seen at days 6, 9 and 12 could be a differentiating factor for these supercontractile cells, downregulation studies were conducted. Two methods of downregulation were used, as follows: 1) treatment of the arrested cells with decorin, which returned the arrested cells to a partially proliferating state; and 2) transfection of the cells with Adv-dn-T $\beta R-I I$, which produced the same change [33, 34].

To determine whether TGF- $\beta$ added exogenously to the culture media of proliferating and arrested (serum-starved) cells would show the same qualitative effects as those of the arrested cells alone, appropriate experiments were carried out (fig. 4). Figure 4 depicts cell length as a function of days in culture, and clearly shows the difference in cell lengths between proliferating and arrested cells.
Interestingly, while the proliferating cells start at a smaller length than expected, they show a progressive increase with time, right up to day 14 . The arrested cells show a sharp increase on day 1 and with no exogenously added TGF- $\beta$. This is likely to be due to the production of endogenous TGF- $\beta$ and its export to the culture medium. At a concentration of $1 \mathrm{ng} \cdot \mathrm{mL}^{-1}$ of exogenously added TFG- $\beta$, a considerable increase in cell length is observed. Thereafter, at concentrations of 10 and $20 \mathrm{ng} \cdot \mathrm{mL}^{-1}$, cell length diminishes to that of the proliferating cells. One explanation for this behaviour is the contact inhibition that occurs in the serum-deprived cells whenever the cells are increasing in length and contacting each other [35-37]. It must be noted that, although the number of cells is greater in proliferating cultures, the amount of cytoplasm in the arrested cells is much greater and establishes intercellular contact much more easily.

Further proof of the role of TGF- $\beta$ was provided by showing that specific second-messenger signalling could be initiated by TGF- $\beta$. In the arrested cells, immunocytochemical phosphospecific Smad2 antibodies demonstrated expression of phosphorylated Smad2 in the cytoplasm. Its presence in the nucleus indicates the occurrence of translocation and the likelihood of its involvement in gene expression. To delineate downstream mechanisms, further studies of smooth muscle $22 \alpha$ promoter activation and of MHC and MLCK promoter activation will be conducted in the future, along with assessment of the activities of inducer and co-repressor molecules, and activation of specific genes.

The conversion of cells from proliferative to differentiated type is not unique, as similar findings have been reported by Li et al. [27]. At present, it is only possible to speculate about gaining insight into the significance of smooth muscle differentiation. Were these cells to develop in the airways of asthmatics, they could contribute considerably to bronchoconstriction. The scenario exists that inflammatory exudates appear during an acute attack of asthma, and the growth factors that they contain lead to airway myocyte hyperplasia and hypertrophy, which in turn lead to airway obstruction. Once the acute attack subsides, a state akin to that of the present study's cultured cells grown in serum-deprived media could then develop, with the resultant development of the supercontractile cell phenotype. Its timing would occur at the time of emergence of nonspecific hyperreactivity of the airways, which commonly follow an acute attack of asthma. ZHOU et al. [38] have reported similar findings in cultured human bronchial smooth muscle cells.

\section{ACKNOWLEDGEMENTS}

The authors would like to thank P. Lowe for carrying out expert word processing.

\section{REFERENCES}

1 Ebina M, Takahashi T, Chiba T, Motomiya M. Cellular hypertrophy and hyperplasia of airway smooth muscles underlying bronchial asthma. A 3-D morphometric study. Am Rev Respir Dis 1993; 148: 720-726.

2 Ebina M, Yaegashi H, Chiba R, Takahashi T, Motomiya M, Tanemura M. Hyperreactive site in the airway tree of asthmatic patients revealed by thickening of bronchial 
muscles. A morphometric study. Am Rev Respir Dis 1990; 141: 1327-1332.

3 Hamid Q, Song Y, Kotsimbos TC, et al. Inflammation of small airways in asthma. J Allergy Clin Immunol 1997; 100: $44-51$.

4 Johnson PR, Roth M, Tamm M, et al. Airway smooth muscle cell proliferation is increased in asthma. Am J Respir Crit Care Med 2001; 164: 474-477.

5 Kraft M, Djukanovic R, Wilson S, Holgate ST, Martin RJ. Alveolar tissue inflammation in asthma. Am J Respir Crit Care Med 1996; 154: 1505-1510.

6 Ma X, Cheng Z, Kong H, et al. Changes in biophysical and biochemical properties of single bronchial smooth muscle cells from asthmatic subjects. Am J Physiol Lung Cell Mol Physiol 2002; 283: L1181-L1189.

7 Reddy KB, Howe PH. Transforming growth factor beta 1mediated inhibition of smooth muscle cell proliferation is associated with a late G1 cell cycle arrest. J Cell Physiol 1993; 156: 48-55.

8 Vignola AM, Chanez P, Chiappara G, et al. Transforming growth factor-beta expression in mucosal biopsies in asthma and chronic bronchitis. Am J Respir Crit Care Med 1997; 156: 591-599.

9 Imai K, Hiramatsu A, Fukushima D, Pierschbacher MD, Okada Y. Degradation of decorin by matrix metalloproteinases: identification of the cleavage sites, kinetic analyses and transforming growth factor-beta1 release. Biochem J 1997; 322: 809-814.

10 Koli K, Saharinen J, Hyytiainen M, Penttinen C, Keski-Oja J. Latency, activation, and binding proteins of TGF-beta. Microsc Res Tech 2001; 52: 354-362.

11 Khalil N, Parekh TV, O'Connor RN, Gold LI. Differential expression of transforming growth factor-beta type I and II receptors by pulmonary cells in bleomycin-induced lung injury: correlation with repair and fibrosis. Exp Lung Res 2002; 28: 233-250.

12 Lawrence DA, Pircher R, Kryceve-Martinerie C, Jullien P. Normal embryo fibroblasts release transforming growth factors in a latent form. J Cell Physiol 1984; 121: 184-188.

13 Lee YC, Lee HB, Rhee YK, Song CH. The involvement of matrix metalloproteinase-9 in airway inflammation of patients with acute asthma. Clin Exp Allergy 2001; 31: 1623-1630.

14 Voss B, Glossl J, Cully Z, Kresse H. Immunocytochemical investigation on the distribution of small chondroitin sulfate-dermatan sulfate proteoglycan in the human. J Histochem Cytochem 1986; 34: 1013-1019.

15 Yamaguchi Y, Mann DM, Ruoslahti E. Negative regulation of transforming growth factor-beta by the proteoglycan decorin. Nature 1990; 346: 281-284.

16 Hildebrand A, Romaris M, Rasmussen LM, et al. Interaction of the small interstitial proteoglycans biglycan, decorin and fibromodulin with transforming growth factor beta. Biochem J 1994; 302: 527-534.

17 Lin HY, Wang XF, Ng-Eaton E, Weinberg RA, Lodish HF. Expression cloning of the TGF-beta type II receptor, a functional transmembrane serine/threonine kinase. Cell 1992; 68: 775-785.

18 Vogel KG, Paulsson M, Heinegard D. Specific inhibition of type I and type II collagen fibrillogenesis by the small proteoglycan of tendon. Biochem J 1984; 223: 587-597.
19 Brand T, MacLellan WR, Schneider MD. A dominantnegative receptor for type beta transforming growth factors created by deletion of the kinase domain. J Biol Chem 1993; 268: 11500-11503.

20 Heldin $\mathrm{CH}$, Miyazono K, ten Dijke P. TGF-beta signalling from cell membrane to nucleus through SMAD proteins. Nature 1997; 390: 465-471.

21 Shi Y, Wang YF, Jayaraman L, Yang H, Massague J, Pavletich NP. Crystal structure of a Smad MH1 domain bound to DNA: insights on DNA binding in TGF-beta signaling. Cell 1998; 94: 585-594.

22 Tao F, Chaudry S, Tolloczko B, Martin JG, Kelly SM. Modulation of smooth muscle phenotype in vitro by homologous cell substrate. Am J Physiol Cell Physiol 2003; 284: C1531-C1541.

23 Xiao Z, Liu X, Lodish HF. Importin beta mediates nuclear translocation of Smad 3. J Biol Chem 2000; 275: 23425-23428.

24 Yamamoto $\mathrm{H}$, Ueno $\mathrm{H}$, Ooshima A, Takeshita A. Adenovirus-mediated transfer of a truncated transforming growth factor-beta (TGF-beta) type II receptor completely and specifically abolishes diverse signaling by TGF-beta in vascular wall cells in primary culture. J Biol Chem 1996; 271: 16253-16259.

25 Zhang Y, Feng X, We R, Derynck R. Receptor-associated Mad homologues synergize as effectors of the TGF-beta response. Nature 1996; 383: 168-172.

$26 \mathrm{Yu} \mathrm{Q}$, Stamenkovic I. Cell surface-localized matrix metalloproteinase-9 proteolytically activates TGF-beta and promotes tumor invasion and angiogenesis. Genes Dev 2000; 14: 163-176.

27 Li S, Sims S, Jiao Y, Chow LH, Pickering JG. Evidence from a novel human cell clone that adult vascular smooth muscle cells can convert reversibly between noncontractile and contractile phenotypes. Circ Res 1999; 85: 338-348.

28 Halayko AJ, Salari H, Ma X, Stephens NL. Markers of airway smooth muscle cell phenotype. Am J Physiol 1996; 270: L1040-L1051.

29 National Center for Biotechnology Information. www. ncbi.nlm.nih.gov/Education/BLASTinfo/information3.html. Date last accessed: July, 18: 2007.

30 Redington AE, Roche WR, Holgate ST, Howarth PH. Colocalization of immunoreactive transforming growth factorbeta 1 and decorin in bronchial biopsies from asthmatic and normal subjects. J Pathol 1998; 186: 410-415.

31 Halayko AJ, Camoretti-Mercado B, Forsythe SM, et al. Divergent differentiation paths in airway smooth muscle culture: induction of functionally contractile myocytes. Am J Physiol 1999; 276: L197-L206.

32 Aubert JD, Dalal BI, Bai TR, Roberts CR, Hayashi S, Hogg JC. Transforming growth factor beta 1 gene expression in human airways. Thorax 1994; 49: 225-232.

33 Zhao J, Bu D, Lee M, Slavkin HC, Hall FL, Warburton D. Abrogation of transforming growth factor-beta type II receptor stimulates embryonic mouse lung branching morphogenesis in culture. Dev Biol 1996; 180: 242-257.

34 Zhao J, Sime PJ, Bringas P Jr, Gauldie J, Warburton D. Epithelium-specific adenoviral transfer of a dominantnegative mutant TGF-beta type II receptor stimulates embryonic lung branching morphogenesis in culture and potentiates EGF and PDGF-AA. Mech Dev 1998; 72: 89-100. 
35 Martz E, Steinberg MS. Movement in a confluent 3T3 monolayer and the causes of contact inhibition of overlapping. J Cell Sci 1974; 15: 201-216.

36 Gos M, Miloszewska J, Swoboda P, Trembacz H, Skierski J, Janik P. Cellular quiescence induced by contact inhibition or serum withdrawal in C3H10T1/2 cells. Cell Prolif 2005; 38: 107-116.
37 Ceccarini C, Eagle H. pH as a determinant of cellular growth and contact inhibition. Proc Natl Acad Sci USA 1971; 68: 229-233.

38 Zhou L, Li J, Goldsmith AM, et al. Human bronchial smooth muscle cell lines show a hypertrophic phenotype typical of severe asthma. Am J Respir Crit Care Med 2004; 169: 703-711. 